\title{
Reform and Practice of Algorithms and Programming Practice Course on Ideological and Political Education and Ability Training
}

\author{
Zhou Zhiguo \\ College of Information Science and Technology \\ Northeast Normal University \\ Changchun, Jilin, China
}

\author{
Zheng Wei \\ Admission Office \\ Northeast Normal University \\ Changchun, Jilin, China
}

\author{
Li Jiahui \\ College of Information Science and Technology \\ Northeast Normal University \\ Changchun, Jilin, China \\ Deng Chunyan* \\ College of Computer Science and Technology \\ Jilin University \\ Changchun, Jilin, China
}

\begin{abstract}
In view of the phenomenon of "two skins" in ideological and political education and professional teaching in colleges and universities, this paper proposes the reforming ideas of ideological and political education and ability training. This thinking comprehensively considers the professional characteristics of the course and the characteristics of Post-00 College students. Taking the practical course of algorithmic and programming as an example, this paper focuses on five aspects: renewing educational concept, revising curriculum objectives, innovating curriculum content, reforming teaching strategies, and establishing continuous improvement mechanism, so as to integrate ideological and political education into professional courses in an organized way, and to explore new ways for training new subject professionals in the new era of all-round development of morality, intelligence, physical, art and labor. Finally, we solicited feedback and explained.
\end{abstract}

Keywords-ideological and political theory of curriculum; engineering practice ability; output orientation; teaching reform

\section{INTRODUCTION}

At the Conference on Ideological and Political Work in the universities, General Secretary Xi Jinping stressed that we should enhance the affinity and pertinence of the ideological and political education, meet the needs and expectations of students' growth and development, at the same time emphasized that "other courses should keep a good canal and cultivate a good responsibility field, so that all kinds of courses and ideological and political theory courses can go in the same direction , family form a synergistic effect."[1] The fundamental problem of higher education is around the issue of "educating people". To accomplish the work of "people cultivating", it is far from enough to rely on the ideological and political theory course and the work of its teachers. It is necessary to let the professional courses occupying the main time and space in the university classroom carry out ideological

Teacher Education Research Fund Project of Northeast Normal University (JSJY20180305) and political work[2-4]. The traditional teaching of professional courses only focuses on the imparting of professional knowledge, but ignores the educational function of the course itself. In order to cultivate students with all-round development of moral, intellectual, physical, art and labor in the new era, professional teachers have the duty and responsibility to integrate knowledge imparting, ability training and thought guidance into the whole process of professional courses teaching. With the function of "implicit ideological and political education" and the same direction as "explicit ideological and political theory" course, we should construct the whole curriculum education bureau.

\section{RENEWAL OF EDUCATIONAL IDEAS}

Knowledge imparting, ability training and value guidance are the basic forms of "educating people" and the most effective realization forms in the universities. In the teaching of professional courses, we should not only focus on the cohesion of knowledge in value dissemination, but also on value guidance in knowledge dissemination. In order to construct the computer course with both ideological and political education and ability training, we should first start with renewing the educational concept.

\section{A. Ideological and political theory of curriculum}

Ideological and political theory of curriculum is a form of ideological and political education relying on the curriculum. It combines the principles, requirements and contents of ideological and political course with curriculum design, textbook development, curriculum implementation and curriculum evaluation by means of recessive education. Strengthening ideological and political education of college students with professional skills and knowledge as the carrier has strong persuasion and appeal. It is helpful to maximize the function of the main channel of the classroom and reverse the phenomenon that the teaching of specialized courses attaches 
more importance to intelligence than morality. It has the irreplaceable advantages of other educational methods. Therefore, teachers of professional courses should combine the content characteristics of professional courses and actively tap the ideological and political elements in the curriculum, enhance their ideological and political literacy and ideological and political education ability. While imparting knowledge and cultivating ability, moisten things silently to guide students to establish correct world outlook, outlook on life and values.

\section{B. Ability Development}

2017 In August of 2000, Mr. Jiang Zongli, Vice-Chairman of the Teaching Steering Committee of Computer Major of the Ministry of Education, pointed out in the "Computer Major Reform Under the background of New Engineering Subject Construction" that "the elite education mode has been unable to adapt well to the reality of talent training in the stage of popular education. In the stage of popular education, education must be designed and implemented according to how the educated can better meet the needs of society [8]

The main purpose of university education is to train talents to meet the needs of social development. Under the background of new engineering subject construction, the curriculum should be based on the following principles: "student-centered, outputoriented and continuous improvement", focus on developing students' ability to solve complex engineering problems [9-11].

- Student-centered. Emphasis is placed on students' autonomous learning. Teachers, as guides, help students achieve expected results through strategies such as diagnosis, evaluation, feedback and constructive intervention.

- Output orientation. Set goals, content and implementation by output. Find ways to help "flowers in greenhouse" understand the needs of social development and enhance students' ability to solve complex engineering problems.

- Continuous improvement. Courses should establish a continuous improvement mechanism, so that teaching is always in a state of continuous improvement, and the quality of teaching is constantly improving [12].

\section{ThOUGHTS AND IMPLEMENTATION OF CURRICULUM REFORM}

Considering the specialty characteristics and students' characteristics of the practical course of arithmetic and program design, the curriculum reform is mainly carried out from four aspects: revising curriculum objectives, innovating curriculum contents, reforming teaching strategies and establishing continuous improvement mechanism. The practical course of arithmetic and program design is constructed, which focuses on both ideological and political education and ability training.

\section{A. Revision of curriculum objectives}

A professional course can only partly support the graduation requirements of the major. All the courses in the curriculum system support all the graduation requirements. Then, through the achievement of the graduation requirements of the major, we can finally achieve the support of the graduation requirements stipulated in the "National Standard for Teaching Quality of Computer Specialty"[13](hereinafter referred to as the "Standard").In this system, the course focuses on supporting the graduation requirements 2: "Familiar with the basic concepts, basic theories, basic knowledge and basic skills of this major, solid mathematical foundation and basic theory and knowledge of computer specialty, basic methods of analysis and design of computer system, basic ability of researching and developing computer software and hardware." Graduation Requirements 4: "Have the knowledge structure and ability structure related to this major, and the ability to apply knowledge comprehensively; have the ability to analyze and solve problems independently and expand the ability to acquire new knowledge by oneself." And then partially support the "Standards" graduation requirements 1: "Engineering knowledge: Can apply mathematics, natural science, engineering foundation and professional knowledge to solve complex engineering problems." "Standards" graduation requirements 2: "Problem analysis: can apply the basic principles of mathematics, natural science and engineering science to identify, express and analyze complex engineering problems through literature research to obtain effective conclusions." The supporting relationship of this course to professional graduation requirements is shown in Table I. By partially achieving professional graduation requirements, and finally achieving the "Standard" graduation requirements

TABLE I. Supporting Relations between Course Objectives and Professional Graduation Requirements

\begin{tabular}{|c|c|c|c|}
\hline $\begin{array}{l}\text { Professional } \\
\text { Graduation } \\
\text { Requirements }\end{array}$ & $\begin{array}{l}\text { Knowledge } \\
\text { Objectives of } \\
\text { Courses }\end{array}$ & $\begin{array}{l}\text { The Ability } \\
\text { Objectives of } \\
\text { the Course }\end{array}$ & $\begin{array}{c}\text { The Ideological } \\
\text { and Political } \\
\text { Objectives of the } \\
\text { Course }\end{array}$ \\
\hline $\begin{array}{l}\text { Graduation } \\
\text { Requirements } 2\end{array}$ & $\begin{array}{l}\text { To enable } \\
\text { students to } \\
\text { acquire basic } \\
\text { theory, basic } \\
\text { knowledge and } \\
\text { basic skills in } \\
\text { algorithm and } \\
\text { programming }\end{array}$ & $\begin{array}{l}\text { Training } \\
\text { students ability } \\
\text { to use basic } \\
\text { algorithm } \\
\text { programming } \\
\text { flexibly to solve } \\
\text { practical } \\
\text { engineering } \\
\text { problems }\end{array}$ & $\begin{array}{l}\text { Cultivate the ideal } \\
\text { feelings } \\
\text { patriotism, } \\
\text { dedication } \\
\text { courage; } \\
\text { Cultivate the spirit } \\
\text { of the times that } \\
\text { students are not } \\
\text { afraid of hardships } \\
\text { and bravely climb } \\
\text { the peak; }\end{array}$ \\
\hline $\begin{array}{l}\text { Graduation } \\
\text { Requirements } 4\end{array}$ & $\begin{array}{l}\text { To enable } \\
\text { students to } \\
\text { acquire } \\
\text { knowledge } \\
\text { structure related } \\
\text { to Algorithms }\end{array}$ & $\begin{array}{l}\text { Students learn to } \\
\text { summarize and } \\
\text { improve their } \\
\text { ability to carry } \\
\text { out scientific } \\
\text { research and } \\
\text { engineering } \\
\text { practice }\end{array}$ & $\begin{array}{l}\text { Cultivate the } \\
\text { scientific spirit of } \\
\text { exploring, seeking } \\
\text { truth and being } \\
\text { pragmatic; } \\
\text { Cultivate the } \\
\text { principles of unity, } \\
\text { integrity and } \\
\text { collaboration }\end{array}$ \\
\hline
\end{tabular}

In addition, the curriculum combines the characteristics of engineering subject, integrates socialist core values into the teaching and strengthens the ideals, beliefs, value orientation, political beliefs and social responsibility of college students. The curriculum added ideological and political objectives on the basis of the original knowledge objectives and ability objectives, and made clear the direction for the ideological and political from Table I. We can see that the teaching core of this course has expanded from knowledge imparting and ability training to knowledge ability and ideological and political 
quality. Therefore, the reform of curriculum content and every

link of curriculum teaching are carried out around this core.

TABLE II. Examples of Ideological and political content catalogue

\begin{tabular}{|c|l|l|}
\hline Course content & \multicolumn{1}{|c|}{ Value-led curriculum content } & \multicolumn{1}{c|}{ Course Content of Building Cultural Confidence } \\
\hline numeration theme & $\begin{array}{l}\text { When facing different life choices, we should } \\
\text { focus on the interests of the country. When } \\
\text { personal interests conflict with national } \\
\text { interests, we should sacrifice personal interests. }\end{array}$ & $\begin{array}{l}\text { To worry before the common people worries; to enjoy only after the people can enjoy. } \\
\text {--Fan Zhongyan "Notes on the Yueyang Tower " } \\
\text { ifle? --XuXilin"Out of the Fortress" } \\
\text { ide the nation, why not return the body to horse's } \\
\text { Over the years, the achievements and fame are as slight as dust. For thousands of } \\
\text { miles, we saw only clouds and moons in the sky.--YueFei "The Whole River Red " }\end{array}$ \\
\hline $\begin{array}{c}\text { Achievements are reached by hard work rather than recreation. Actions are done after } \\
\text { high precision } \\
\text { computing theme }\end{array}$ & $\begin{array}{l}\text { Establish the professionalism in the work.Even consideration rather than casual decision. --Han Yu "To learn". } \\
\text { the smallest mistake can lead to huge losses. }\end{array}$ & $\begin{array}{l}\text { A gentleman' self-cultivation is like a bone processor, which needs negotiation when } \\
\text { cut; like a jade processor, which needs grinding when cut. --"The Book of Songs" }\end{array}$ \\
\hline
\end{tabular}

\section{B. Construction of Course Content}

\section{1) Attach Importance to Guiding and Promoting Culture}

According to the ideological goals of the course, the content of the course will be sorted out. Actively explore the elements of moral education in the course, forming a catalogue of ideological and political contents as shown in Table II.It not only adds value-oriented curriculum contents, guides students to establish correct outlook on world, life and values, but also adds curriculum contents that help to spread Chinese culture and help students build cultural self-confidence.

\section{2) Output orientation and capacity improvement}

Output-oriented curriculum content updates are shown in Table III. Firstly, on the basis of the original theoretical knowledge, new engineering practice cases are added according to the needs of social development and the knowledge goal and ability goal of the curriculum; secondly, the relevant knowledge points in the algorithm competition are integrated into the existing teaching content to improve students' computing thinking ability; Thirdly, the algorithms and management processes involved in scientific research and engineering projects are introduced into the classroom [14]. To infuse fresh blood into teaching and keep the content of courses in line with the development of the times.

\section{Teaching Strategy Design}

In order to effectively carry out the teaching devoted to the cultivation of knowledge ability and value guidance, the design of teaching strategies should focus on the following four aspects.

\section{1) Student-centered teaching method}

Through classroom teaching, group discussions, student speech with teacher evaluation, student assessment with teacher evaluation, and other interactive teaching forms, students are organized to discuss professional knowledge, and guide students to take the initiative to learn. Outside the classroom, we should make full use of the "Internet+" environment to rationally distribute teaching resources to classroom, online platforms and mobile terminals, and encourage students to learn online for completing their learning tasks by using fragmented time. Through this threedimensional teaching mode, the teaching space-time is extended from theoretical teaching in the classroom to practical teaching outside the classroom, from theory to competition.
Nowadays, the main body of college students in campus is the post-00 generation, who grew up under the background of the rapid development of the Internet and mobile Internet. They are the aborigines of the Internet era. They have a wide range of interests, realistic learning goals, and their life and learning depend on the Internet. They have formed the habit and ability of obtaining learning resources from the Internet. The course combines their growing background and learning characteristics to develop online platform [15] and mobile autonomous learning. This new learning mode complies with the learning habits and thinking modes of this generation of college students. The methods of teacher-student interaction and student-student interaction are helpful to stimulate students interest in learning, arouse students' active thinking, and then arouse students' learning enthusiasm and creativity, so that students love learning and learning from the heart.

\section{2) Output-oriented instructional design}

According to the requirement of graduation ability, reverse design teaching strategy. In the classroom, students are organized to analyze, design and develop engineering cases or scientific research projects. Then through teaching strategies such as team-teaching method and cooperative teaching method, Students gradually learn solution of complex engineering problems. Through the teaching activities of "Expert face to face" and "Enterprise practice" outside classrooms, enterprise experts are invited into the classroom and students are brought into the enterprise. On the one hand, students are helped to understand the actual industrial needs of the current new subject construction. On the other hand, students are allowed to participate in the actual project of the enterprise and improve their engineering practice ability.

\section{3) Integration of competition and teaching}

The course will introduce the International Collegiate Programming Contest (abbr. ICPC) and other professional contest topics into the classroom to help students enjoy the top algorithms in the field of computer science. It encourages students to participate in professional contests to further broaden their horizons and enhance their computing thinking ability.

\section{4) Integration of science research and teaching}

The author assists the Student Department to set up a studio to provide a good research environment for students, which guides and encourages undergraduates to actively carry out project practice and scientific research activities, put 
TABLE III. Examples of output-oriented teaching content catalogues

\begin{tabular}{|c|c|c|c|c|}
\hline Course Content & Knowledge Requirements & Ability Requirements & $\begin{array}{l}\text { Contents of Combination of } \\
\text { Competition and Education }\end{array}$ & $\begin{array}{lr}\text { The Content } & \text { of } \\
\text { Combination } & \text { of } \\
\text { Science } & \text { and } \\
\text { Education } & \end{array}$ \\
\hline $\begin{array}{l}\text { Simulation } \\
\text { calculation } \\
\text { theme }\end{array}$ & $\begin{array}{l}\text { Master the simulation } \\
\text { calculation method }\end{array}$ & $\begin{array}{l}\text { The ability to solve complex } \\
\text { engineering problems using } \\
\text { simulation methods. }\end{array}$ & $\begin{array}{l}\text { ACM Competition Question } \\
\text { "Guess the Number Game" } \\
\text { Quoted from Poj.org } 2328\end{array}$ & $\begin{array}{l}\text { Solving network } \\
\text { congestion; calculating } \\
\text { game wins and loses }\end{array}$ \\
\hline $\begin{array}{l}\text { High precision } \\
\text { calculation theme }\end{array}$ & $\begin{array}{l}\text { Master the high precision } \\
\text { calculation process; } \\
\text { Master the ability to process } \\
\text { high precision data input, } \\
\text { storage and operation }\end{array}$ & $\begin{array}{l}\text { The ability to solve complex } \\
\text { engineering problems by high } \\
\text { precision method }\end{array}$ & $\begin{array}{l}\text { ACM Competition Question } \\
\text { "Addition of Super Large } \\
\text { Integers" } \\
\text { Quoted from poj.grids.cn } 2981\end{array}$ & $\begin{array}{l}\text { Numerical calculation in } \\
\text { aerospace field; } \\
\text { calculation of } \\
\text { meteorological data }\end{array}$ \\
\hline
\end{tabular}

creative thinking and ideas into practice, and internalize their knowledge into professional competence.

\section{The Change of Evaluation and Assessment Method}

The way of course assessment and achievement evaluation supports the achieving of the graduation requirements in Table I.

1) Implementing an open and whole-process assessment centered on training students' engineering practice ability. The course greatly enhances the proportion of the scores of online practices and ordinary independent OJ exercises, emphasizing the process of ability cultivation.

TABLE IV. Ratio of Achievements

\begin{tabular}{|l|l|l|l|l|}
\hline $\begin{array}{l}\text { Total test } \\
\text { scores/\% }\end{array}$ & $\begin{array}{l}\text { Final } \\
\text { OJ } \\
\text { score/\% }\end{array}$ & $\begin{array}{l}\text { Mid-term } \\
\text { OJ } \\
\text { scores/\% }\end{array}$ & $\begin{array}{l}\text { Classroom OJ } \\
\text { Exercise/\% }\end{array}$ & $\begin{array}{l}\text { Independent OJ } \\
\text { Practice/\% }\end{array}$ \\
\hline 100 & 50 & 20 & 20 & 10 \\
\hline
\end{tabular}

Online Judge (abbr. OJ) is used in the whole process of assessment. The focus of assessment is upgraded from the past "assessment of the mastery of knowledge points" to "the ability to solve complex engineering problems after knowledge internalization".

2) Developing descriptive ideological and political evaluation

According to the content of ideological and political work, we should adopt the principles of process evaluation, qualitative evaluation and developmental evaluation. We can use the methods of archives of ideological development, key events and evaluation forms, mainly to evaluate the changes of students' emotions, attitudes and values in professional learning, professional loyalty, recognition of professional value, ethics in discipline and professional ethics, and the ability to analyze social phenomena related to discipline.

\section{TEACHING FEEDBACK}

In order to obtain feedback on the teaching effect, the course team conducted questionnaires to students of 2016 and 2017 who had completed the course, and solicited opinions and suggestions on the course teaching. A total of 119 questionnaires were distributed, including 3 invalid questionnaires and 116 valid questionnaires. Feedback information was as follows:

- For the reform of teaching content, among the students who participated in the questionnaires, $12.07 \%$, $39.66 \%, 38.79 \%$ and $9.48 \%$ thought that the curriculum content was difficult, relatively difficult, moderate and easy, respectively;

- For the reform of teaching strategies, $55.17 \%$ of the students think that OJ-type test can more truly reflect their programming ability. $68.1 \%$ of the students think that online exercises and online exams can improve their programming ability; $62.93 \%$ of the students think that participating in enterprise visits can help them understand the current social development needs; $59.48 \%$ of the students think that participating in "industry experts face to face" activities can help them understand the current development situation and industry needs.90.52\% of the students understand that the engineering practice ability of the students is the key to the recruitment of computer-related jobs;

- $82.76 \%$ of the students think that the course is helpful to improve the ability of computing thinking, and $81.9 \%$ of the students think that it plays a supporting role in improving the engineering practice ability.

From the final evaluation results and the feedback from the students' questionnaires, the curriculum has basically reached the expectations and achieved the following results:

- The three-dimensional teaching model is welcomed by students, students are willing to become the dominant learners from passive learning to active learning;

- Combination of competition and education and integration of science and education can effectively help students improve their ability of computing thinking and engineering practice;

- Collaboration between schools and enterprises can effectively help college students understand the current status of the industry development and industry needs;

- The reform of teaching strategies can effectively help students internalize their knowledge into the ability to solve complex engineering problems.

As the first round of ideological and political education for undergraduates in 2018 is now being carried out, the teaching cycle has not yet ended. The feedback data obtained from the follow-up survey will be mainly used to improve teachers' teaching and enhance teachers' ideological and political education ability.

The problems in the curriculum reform process are also exposed from the questionnaire data. For example, only $49.14 \%$ 
of the students who participated in the questionnaires believed that going to the enterprise to practice would help improve their engineering practice ability. This phenomenon warns that the teachers of the course should supervise the concrete implementation of the enterprise practice, so as to avoid making the opportunity of engineering practice become a mere formality.

\section{ESTABLISHMENT OF CONTINUOUS IMPROVEMENT MECHANISM}

The curriculum has established a long-term improvement mechanism. The curriculum syllabus is fine-tuned every year, based on reasonable evaluation opinions such as teaching quality evaluation, student questionnaire feedback, graduate feedback information and social evaluation results, combined with national policies, social development needs, professional and curriculum positioning and education and teaching reform. Overhaul is scheduled every four years.

\section{CONCLUSION}

Through the results of the survey and feedback from the current and previous students, the course team of Algorithms and Programming Practice can timely find the problems in the teaching process and actively improve the quality of teaching. With the advancement of ideological and political education and new engineering construction, and the deepening understanding of the concept of "building people by virtue", the curriculum team will continue to adhere to the unity of professional knowledge imparting and education objectives. In order to train computer professionals in the new era of allround development of morality, intelligence, physical fitness, beauty and labor, we will deepen the reform of the curriculum, and compare the results of the survey and feedback with the intended teaching objectives, so that the teaching of the curriculum will always be in a state of continuous improvement.

\section{REFERENCES}

[1] Communist Party of China News Network.Xi Jinping emphasized: Putting ideological and political work through the whole process of education and teaching and creating a new situation in the development of higher education in China at the National Conference on Ideological and Political Work in Colleges and Universities [EB/OL]. (2016-12-09) [2019-05-28]. http://dangjian.people.com.cn/n1/2016/1209/c11709228936962.html. (In Chinese)
[2] Ministry of Education. Ministry of Education's 2019 work points [EB/OL]. (2019-03-10) [2019-05-28]. (In Chinese) http://www.gov.cn/xinwen/2019-03/10/content_5367914.htm.

[3] ChenBaosheng.Universities must adhere to the correct political direction. [EB/OL]. (2017-02-06)[2019-05-28]. http://www.gov.cn/xinwen/2017-02/06/content_5165697.htm. (In Chinese)

[4] Party Group of the Ministry of Education. Notice of the Party Group of the Ministry of Education of the Communist Party of China on Printing and Distributing "the outline for the implementation of the quality improvement project for ideological and political work in the universities". [EB/OL]. (2017-12-05)[2019-05-28]. http://www.moe.gov.cn/srcsite/A12/s7060/201712/t20171206_320698. html. (In Chinese)

[5] Gaodeyi,ZhongAidong.From ideological and political course to course ideological and political course: Constructing ideological and political education course system in the Universities from a Strategic Perspective [J].Higher education in China,2017(1): 45-48. (In Chinese)

[6] LuDaokun.Some Core Problems and Solutions in the Course Ideological and Political Implementation-Discussion on Ideological and Political Education Based on Professional Courses [J]. Ideological and theoretical education, 2018(03):64-69. (In Chinese)

[7] Tan Xiaoshuang.Analysis on the Value Connotation and Practice Path of Curriculum Ideological Management [J]. Ideological and political work education, 2018(04):44-45. (In Chinese)

[8] Department of Higher Education.Notice of the Higher Education Department of the Ministry of Education on the research and practice of new engineering. [EB/OL].(2017-02-20)[2019-0528].http://www.moe.edu.cn/s78/A08/A08_gggs/A08_sjhj/201702/t2017 0223_297158.html. (In Chinese)

[9] Jiang Zongli.Computer Professional Reform under the Background of New Engineering Construction [J].China University Teaching,2017(8):34-39. (In Chinese)

[10] Jiang Zongli.Undergraduate Engineering Education : Focus on the Cultivation of Students' Ability to Solve Complex Engineering Problems [J].China University Teaching,2016(11):27-30. (In Chinese)

[11] Lin Jian.How to Understand and Solve Complex Engineering Problems: Definition and Requirements Based on Washington Agreement [J]. Research on Higher Engineering Education,2016(5):17-26. (In Chinese)

[12] Deng Chunyan, Zhou Zhiguo, Chen Juan,LvShuai.Teaching Reform and Practice of Programming Basic Course esignunderD the Background of Engineering Education Certification [J].Computer Education, 2019.05:68-72. (In Chinese)

[13] Jiang Zongli.Developing Computer Major Studentswith the Ability to Solve Complex Engineering Problems [M].Beijing:Tsinghua University Press ,2018.07:169-177. (In Chinese)

[14] Chen Juan, Zhang Changhai, Deng Chunyan, Li He.Construction and Thinking of massive open online course for Advanced Language Programming Course [J].Computer Education,2017.01:9-13. (In Chinese)

[15] Zhou Z, Gao B, Zou M, et al. The Research and Practice of Program Design Based on MultipleNetworks Teaching Mode[C]//DEStech Publications Inc.2015 2nd International Conference onEducation and Social Development. DEStech Publications Inc, 2015:383-388. 